\title{
Effect of dietary replacement of yellow corn energy with culled sweet potato (as non traditional energy source) on growth performance, nutrients utilization and carcass traits of growing Nile Tilapia (Oreochromis niloticus)
}

\section{Nabil F. Abd El-Hakim; Mohamed, M. Lashin; Al-desoki, A. M. Al- Azab and Ahmed, M. Fahim}

AL-Azhar university, Faculty of Agriculture, Department of Animal Production, Cairo, Egypt.

\begin{abstract}
$\mathrm{T}$ he present study aimed to evaluate the effect of incorporation of culled inedible sweet potato root (as non-traditional energy source) to replace yellow corn energy in growing mono-sex Nile tilapia (Oreochromis niloticus) diets on the fish performance, nutrients utilization, whole body composition and carcass traits. The study was carried out in concrete ponds $(7.5 \mathrm{~m}$ length $\times 2.25 \mathrm{~m}$ width $\times 0.70 \mathrm{~m}$ water depth). Each pond was divided by fine nets into three equal parts $(2.5 \times 2.25 \times 0.70 \mathrm{~m}$ each $)$ to represent four treatments; the control (CSP0); the 25 (CSP25); 50 (CSP50) and 100\% (CSP100) culled sweet potato, respectively. Each dietary treatment was carried out in triplicates and the treatments were stocked with Nile tilapia fry $(0.31 \mathrm{~g}$ initial weight $)$ at a rate of 20 fish $/ \mathrm{m}^{3}$ i.e. 80 fish in each replicate. The experimental diets were formulated to be iso nitrogenus and iso caloric and contained about $33 \%$ crude protein and $4500 \mathrm{kcal} \mathrm{GE} / \mathrm{kg}$. The experimental diets were fed at daily rates of 30;10;6 and $4 \%$ of the fish biomass for fish weight from start to $1 \mathrm{~g} ; 1-5 \mathrm{~g} ; 5-20 \mathrm{~g}$ and $20 \mathrm{~g}$ respectively till the end of the experiment after 22 weeks. The experimental diets were offered in equal portions at 9am; $11 \mathrm{am} ; 1 \mathrm{pm}$ and $3 \mathrm{pm}$ respectively.

Results obtained are summarized in the following:

1- Culled sweet potato contained $92.5 ; 6.1 ; 1.0 ; 4.6 ; 3.87$ and $76.93 \%$ dry mater; crude protein; crude fat; ash; crude fiber and NFE, respectively. It contained $3671 \mathrm{kcal}$ growth energy / $\mathrm{kg}$.

2 - Incorporation of culled sweet potato to replace $100 \%$ of yellow corn energy improved significantly final weight and weight gain compared to the 25 CSP and the control group. Replacement of yellow corn energy with CSP at all tested levels released no significant effects on condition factor and survival rate.

3- Incorporation of CSP at 50 and $100 \%$ levels to replace yellow corn energy in Nile tilapia diets showed similar insignificant feed conversion ratio compared to the control group, however both levels improved significantly the protein efficiency ratio compared to the $25 \%$ replacement level. CSP at all tested levels had no significant effects on energy utilization compared to the control group.
\end{abstract}


4- Incorporation of CSP released significant effects on dressing; head; byproducts and flesh percentages compared to the control group.

5- Replacement of yellow corn energy with CSP at 25; 50 and 100\% levels had no significant effects on whole body chemical composition.

6- Replacement of yellow corn energy with CSP energy reduced the costs of one $\mathrm{kg}$ gain in weight by 4.67 and $1.24 \%$ for the CSP50 and CSP100 compared to the control group, respectively; while CSP at $25 \%$ level increased the production costs of one kg gain in weight by $5.72 \%$ compared to the control group.

Based on the obtained results, it could be concluded that culled sweet potato can replace 50 to $100 \%$ of yellow corn energy without adverse effects on growth performance, feed utilization parameters with the advantage of reducing the costs of $1000 \mathrm{Kg}$ gross energy.

Keywords: Nile Tilapia, Oreochromis niloticus, yellow corn, sweet potato, nutrients, growth

\section{INTRODUCTION}

The type of feed and the ingredients which will be used depend on the species of the cultured fish, feed availability and its costs. The fish feed costs represent almost 65 to $70 \%$ of the intensive fish culture costs. Attempts have been done to reduce the feed costs by using cheaper alternative sources of protein and/or energy of what so called non- traditional ingredients or byproducts which may be of great value in producing cheap fish diets (AbdelHakim et al., 2003)

Also, it is well known that yellow corn grains forms the greatest share in Egyptian imported ingredients, accordingly, its cost continues to increase from time to time owing to its universal use as animal feed ingredient.Therefore, there is an urgent need to search for non-traditional feedstuffs or by-products which could be used as cheap sources of protein and energy to replace fish meal and yellow corn in formulating livestock and fish diets.

Sweet potato roots have several shortcomings as an animal feed. They contain little protein - where crude protein content commonly ranges from 1.3 4 per cent, though could run as high as 10 percent of dry matter $(\mathrm{Li}, 1974$; Purcell et al., 1976; Walter et al., 1984) and up to 40 percent of the total nitrogen in sweet potato is non-protein nitrogen. Farmers overcome this constraint by supplementing a sweet potato-based diet with rice bran, fish meal, soy beans or residue, sweet potato and cassava leaves and, to a lesser extent, commercial supplement when these are available and affordable (Purcell et al., 1976).

Middleton et al. (2001), found that extrusion co processing of culled sweet potatoes and poultry silage produce an acceptable feed ingredient for hybrid tilapia that can be included up to $33 \%$ of the diet without adversely affecting growth, market yield, sensory indices, or water quality as compared to 
control diet. Olukunle (2006) evaluated the potential of sweet potato peel meal as a cheaper replacement for maize in the diet of Clarias gariepinus, at levels of $0 \%$ (control), 25,50 , and $75 \%$, and he found that all the diets with sweet potato peel meal inclusion performed better than the control diet. The data indicated that Clarias gariepinus effectively tolerated diets containing sweet potato peel meal at low levels of concentration while fish growth performance and utilization decreased with the increase in the sweet potato peel meal inclusion. Also sweet potato peels meal based diets were cheaper than the control diet.

Omoregie et al. (2009) used incorporation of sweet potato peels in the diet of Oreochromis niloticus up to $25 \%$, and they found that, no significant depression in growth or deleterious effects on health of the fish, which means to a lesser extent (15\%) sweet potato peel was well tolerated by Oreochromis niloticus.

The aim of the present investigation was to study the effect of replacing yellow corn energy in Nile tilapia diets with culled sweet potato energy at different levels on growth performance, nutrient utilization and the costs of gain in weight of the tested fish.

\section{MATERIAL AND METHODS}

The present study was conducted at Water Resources Research Station belonging to the National Institute of Oceanography and Fisheries at Baltim region, Kafr El-sheikh governorate, Egypt. The study started from 1st of June and lasted till 2nd of November 2006 for 22 weeks.

The study included a trail to substitute yellow corn energy with culled sweet potato (CSP) energy in Nile tilapia diet at 25, 50 and $100 \%$ levels.

Preparation of Culled sweet potato (CSP): Culled sweet potato (CSP) was brought from Al-Oboor market, Cairo. The CSP was broken sweet potato and biggest or smallest ones not fit for human consumption. The CSP was cleaned and washed to remove the clime and dust, then left in air to dry. After that, CSP was cut into slices by a chipping machine then left in the sun for ten hour for primary drying. After that, it was dried in an oven at $105^{\circ} \mathrm{C}$ for 24 hour. Then the CSP was grinded to make sweet potato powder for easy mixing and good distributing with other ingredients in experimental diets. After that CSP powder was stored in plastic bags kept away from wetness until used in formulating the experimental diet. Table (1) shows the chemical analysis of culled sweet potato (CSP) compared with yellow corn in dry matter basis.

Table (1): Proximate chemical analysis of culled sweet potato compared with yellow corn.

\begin{tabular}{|l|l|l|}
\hline \multicolumn{1}{|c|}{ Ingredients } & \multicolumn{1}{|c|}{ Culled sweet potato } & \multicolumn{1}{c|}{ Yellow corn } \\
\hline Moisture & 7.5 & 10 \\
\hline Dry matter & 92.5 & 90 \\
\hline Crude protein & 6.1 & 8.5 \\
\hline Crude fat & 1.0 & 4.1 \\
\hline Ash & 4.6 & 2.06 \\
\hline Crude fiber & 3.87 & 2.4 \\
\hline NFE* & 76.93 & 72.94 \\
\hline G.E. K cal/kg** & 3671 & 3881 \\
\hline Calculated by difference & ** Based upon the factor 5.65, 9.45, 4.0 and $4.0 \mathrm{Kcal} / \mathrm{g}$ of protein, ether extract, crude fiber and nitrogen free \\
extract (Jobling, 1983)
\end{tabular}


The experiment included four dietary treatments; the first treatment served as a control and contained yellow corn as main dietary energy source. The second, third and fourth treatments contained CSP to replace yellow corn energy at 25 (CSP25), 50 (CSP50) and 100\% (CSP100) levels respectively. All diets of this experiment were formulated to be iso nitrogenous and iso caloric (33 \% CP and $4500 \mathrm{Kcal} / \mathrm{Kg}$ gross energy). The compositions of the experimental diets are given in Table (2).

Table (2): Composition of the experimental diets used in feeding experiment

\begin{tabular}{|c|c|c|c|c|}
\hline \multirow{2}{*}{ Ingredient $\%$} & \multirow{2}{*}{ T1 control } & \multicolumn{3}{|c|}{ Treatment } \\
\hline & & T2 CSP 25\% & T3 CSP $50 \%$ & T4 CSP $100 \%$ \\
\hline Fish meal (72\%) & 25 & 25 & 25 & 25 \\
\hline Yellow corn & 30 & 22.5 & 15 & - \\
\hline Soybean meal (44 \%) & 25 & 25.9 & 26.6 & 28.4 \\
\hline Rice bran & 12 & 10.2 & 8.8 & 5.6 \\
\hline Vegetable oil & 6 & 6.5 & 6.8 & 7.4 \\
\hline Sweet potato & - & 7.9 & 15.8 & 31.6 \\
\hline Vitamin mixture * & 1 & 1 & 1 & 1 \\
\hline Mineral premix $* *$ & 1 & 1 & 1 & 1 \\
\hline Total & 100 & 100 & 100 & 100 \\
\hline \multicolumn{5}{|c|}{ Calculated composition } \\
\hline Protein & 33.09 & 33.09 & 33.07 & 33.14 \\
\hline Fat & 11.25 & 11.28 & 11.13 & 10.89 \\
\hline Ash & 8.21 & 8.26 & 8.35 & 8.51 \\
\hline G.E. Kcal/Kg*** & 4496 & 4504 & 4501 & 4500 \\
\hline
\end{tabular}

*Each gram of vitamin mixture contains 20.00 IU vit A 200 IU vit ,.De, 400 vit E, 20mg Niacin $4.5 \mathrm{mg}$ riboflavin, $3 \mathrm{mg}$ pyridoxine, $0.013 \mathrm{mg}$ vit B12, $100 \mathrm{mg}$ chcholin chloride and $2 \mathrm{mg}$ vit .k. **Each gram contains $0.83 \mathrm{Ca}, 0.63 \mathrm{P} .078 \mathrm{Na} .0 .018 \mathrm{Mn}, 0.011 \mathrm{Zn}$ and $0.001 \mathrm{Cu}$ The Mixture was prepared by mixing 35 parts of dicalcium phosphate , 3 parts of mineral premix and 2 part of common salt.

*** Based upon the factor 5.65, 9.45, 4.0 and $4.0 \mathrm{Kcal} / \mathrm{g}$ of protein, ether extract, crude fiber and nitrogen free extract (Jobling, 1983)

Experimental fish: Apparently healthy mono-sex Nile tilapia (Oreochromis niloticus) fry (with sex reversed into males with hormone treatment) were purchased from a commercial private fish hatchery located at Kafr El-Sheikh Governorate were used as experimental fish. Fish were acclimated to the experimental water for 7 days before starting the experiment in four fiberglass tanks $\left(1 \mathrm{~m}^{3}\right)$ with small aeration pumps. After acclimation, the fish were randomly distributed into four groups that represented the dietary treatments cited before and stocked in the experimental ponds at a rate of $20 \mathrm{fish} / \mathrm{m}^{3}$ in three replicates each. The initial weight of the experimental fish was $0.31 \mathrm{~g}$ also chemical compositions of fish whole bodies at the start of experiments are showed in Table (3).

Table (3) chemical composition of fish at the start

\begin{tabular}{|c|c|c|c|c|}
\hline Item & Moisture & Protein & Fat & Ash \\
\hline$\%$ & 79.19 & 60.19 & 14.65 & 25.16 \\
\hline
\end{tabular}


Experimental ponds and stocking rate :Four rectangular cement ponds were used in these experiments with dimensions $7.5 \times 2.25$ and 1.1 meter depth for each pond. All ponds were divided into three partitions with sheet of screen with fine mesh size, where every pond had three replicates for one treatment. The experimental ponds before being stocked with fish were drained completely; where bottoms were exposed to sun radiation for one week and treated with potassium permanganate $\left(\mathrm{KMnO}_{4}\right)$. Then the ponds were filled after cleaning up with brackish water to $70 \mathrm{~cm}$ height from underground well by electrical pump for lifting water through pipes and valves to the beginning of ponds. A screen with fine mesh size was used for each pond to prevent escaping of the stocked fishes during the drainage process of water at the end of pond.

The volume of each partition (replicate) was about $4 \mathrm{~m}^{3}(2.5 \times 2.25$ and $0.7 \mathrm{~m}$ water depth) stocked by 80 mono-sex of Nile tilapia fry $\left(20\right.$ fry $\left./ \mathrm{m}^{3}\right)$.

During the experimental period; water was changed and renewed at a rate of $20 \%$ of the water column daily to obtain a good water quality and ponds were drained every two weeks for cleaning the ponds.

Aeration of water was supplied by rotary lobe blower through a plastic pipe and then to a $16 \mathrm{~mm}$ perforated pipes which were laid $50 \mathrm{~cm}$ below the water level.

Feeding rate: The experimental diets were fed in unpelleted powder form during the whole experimental period. The diets were offered for thirteen days every two weeks to allow the cleaning of experimental ponds for one day and to record the fish weight in fish samples for readjusting the new feeding rate according to the rates presented in Table (4). The daily feed amount was distributed daily by hand in four equal portions at 9am, 11am, 1pm and $3 \mathrm{pm}$ according to Kubaryk (1980) (Table 4).

Table (4): Feeding rate of Nile tilapia throughout the experimental period.

\begin{tabular}{|l|c|c|c|c|}
\hline Weight (g) & start -1 & $1-5$ & $5-20$ & 20 - end \\
\hline Feeding rate (\% of b. wt.) & 30 & 10 & 6 & 4 \\
\hline Daily feeding times & \multicolumn{4}{|c|}{ Four meals $(9 \mathrm{am}, 11 \mathrm{am}, 1 \mathrm{pm}, 3 \mathrm{pm})$} \\
\hline
\end{tabular}

Fish samples and measurements: The initial body weight was recorded and the chemical composition of fry whole bodies was carried out at the beginning of the experiments.

Random samples of fish (90 fish / treatment as 30 fish $\times 3$ replicates) were taken once every two weeks during the whole experimental period to record its weight and to calculate the new biomass and adjust feed amounts accordingly. Fish were collected by using nylon net early in the morning and the fish of each pond were kept in a separate plastic tank $\left(1 \mathrm{~m}^{3}\right)$ filled with water from the corresponding pond to avoid any stress on the fish, thereafter the fish were returned to their experimental ponds after recording the data.

At the end of experimental period, individual body weight and total length of fish were recorded for each treatment. 
According to the data of body weight and length, the following parameters were estimated:

\section{Growth performance:}

1- Body weight gain $=\mathrm{W} 2-\mathrm{W} 1$

Where: W2 = Final body weight; W1= Initial body weight

2- Average daily gain $=(\mathrm{W} 2-\mathrm{W} 1) /$ period in day

3- Specific growth rate $\mathrm{SGR}=(\mathrm{Ln} W 2-\mathrm{Ln} W 1) \times 100 / \mathrm{t}$.

Where: $\operatorname{Ln}=(\log 10 \mathrm{x})^{3.303}$

4- Condition factor $(\mathrm{K})=\left[\right.$ weight $(\mathrm{g}) /$ length $\left.^{3}(\mathrm{~cm})\right] \mathrm{x} 100$

5- Survival Rate $(\%)=\mathrm{N} 1 / \mathrm{N} 0 \times 100$

Where: $\mathrm{N} 1=$ Total number of fish survival in pond at end of experiments.

$\mathrm{N} 0=$ Total number of fish in tank at the beginning of experiments.

\section{Feed utilization:}

1 - Food conversion ratio $(\mathrm{FCR})=$ total feed consumption $(\mathrm{g}) /(\mathrm{W} 2-\mathrm{W} 1)$

2 - Protein efficiency ratio $(\mathrm{PER})=(\mathrm{W} 2-\mathrm{W} 1) /$ protein intake $(\mathrm{g})$

3- Protein productive value

$(\mathrm{PPV})=$ Protein retained in tissue $(\mathrm{g}) /$ protein intake $(\mathrm{g}) \times 100$

4- Energy utilization \% $(\mathrm{EU})=(\mathrm{E} 1 \mathrm{-}-\mathrm{E} 0 / \mathrm{EI}) \mathrm{x} 100$

Where: E1 =energy content in fish carcass (Kcal) at the end of experiment

E0 $=$ energy content in fish carcass (Kcal) at the start of experiment

$\mathrm{EI}=$ energy intake $(\mathrm{Kcal})$

\section{Carcass characteristics}

The samples (15 fish/ treatment) were taken randomly after harvesting for carrying-out the carcass characteristics. Body weight, length of each fish in the sample were recorded at first, then the scales and viscera were removed also head and fins were cut then skin was removed, bones were obtained by dipping rest of the body in boiling water. All parts were weighted and recorded to calculate the following.

1 - Dressing percentage $=(($ body weight $-\{$ head + fins + viscera + scales $\}) /$ body weight) $\times 100$

2- Head percentage $=($ head weight $/$ body weight $) \times 100$

3 - By-product percentage $=(\{$ head + fins + viscera + scales + skin + bones $\} /$ body weight) $\times 100$

4- Flesh percentage $=(\{$ body weight - by-product $\}$ / body weight $) \times 100$

\section{Chemical analysis of fish}

Proximate chemical analysis (moisture, protein, fat and ash) of whole fish body was carried out according to the methods described by AOAC (1990) and Lovell (1981)

\section{Water quality:}

Quality of ponds water was checked once per two weeks to determine temperature $\left({ }^{\circ} \mathrm{C}\right)$, dissolved oxygen (DO), transparency Secchi disk visibility (SD), hydrogen ions concentration $(\mathrm{pH})$, Ammonia (NH3) and Total dissolved salt (T.D.S). 
All measurements were carried out according to the standard methods of American Public Health Association (APHA 1985) and Boyd (1992)

1- Water temperature $\left({ }^{\circ} \mathrm{C}\right)$ and dissolved oxygen (DO): According to Boyd (1992), tests of temperature and dissolved oxygen were taken between 7 am and 8 am by inserting the probe of the oxygen meter (YSI 57, USA) by dripping it few centimeters below the water surface (approximately $5 \mathrm{~cm}$ )

2- Secchi disk visibility (S.D) (cm): Estimates of Secchi disk visibility were made on each sampling date. Measurements were made at the same location in each pond according to Boyd (1992).

3-Hydrogen ions (pH): According to Boyd (1992), $\mathrm{pH}$ value was measured by using $\mathrm{pH}$ meter (Coming Co. $\mathrm{pH}$ meter model 345) as soon as samples of water were collected.

4- Ammonia (NH3): Ammonia (mg/l) was calculated from the results of total ammonia according to the following equation:

Ammonia concentration $(\mathrm{mg} / \mathrm{l}$ as NH3) $=\mathrm{A} / 100 \times 1.2 \times$ total ammonia.

Where: $\mathrm{A}$ is a coefficient related to water $\mathrm{pH}$ and temperature at the time of testing (Boyd, 1992).

5- Total dissolved salt (T.D.S): Total dissolved salt was measured by using refractometer (Abbe Model AR-001).

Statistical analysis:

Statistical analysis was performed using the one-way analysis of variance (ANOVA) and Dauncan (1955). Multiple Range Test was done to determine differences between treatment (mean at significance level of $\mathrm{P}<0.05$ ). Standard errors were also estimated. The software used for the statistical analysis was Spss ver. 14 for WINDOWS Xp.

\section{Economical evaluation:}

The Economic evaluation of experimental treatments were done to determine the cost of feed required to produce one $\mathrm{Kg}$ of fish weight gain. The cost of the experimental diets has been done in L.E. for market prices in 2006. Accordingly, the cost of producing one $\mathrm{Kg}$ gain = amount of feed used to produce $1 \mathrm{Kg}$ fish gain $\times$ cost of one $\mathrm{Kg}$ feed. The cost of $1000 \mathrm{kcal}$ gross energy from CSP and from yellow corn was also calculated.

\section{RESULTS AND DISCUSSION}

Water quality: Water quality parameters including water temperature $\left({ }^{\circ} \mathrm{C}\right)$, dissolved oxygen $(\mathrm{DO})$ concentration $(\mathrm{mg} / \mathrm{l})$, water transparency $(\mathrm{cm}), \mathrm{pH}$ (degrees), ammonia $\left(\mathrm{NH}_{3}\right)(\mathrm{mg} / \mathrm{l})$ and total dissolved salts (T.D.S) $(\mathrm{mg} / \mathrm{l})$ are presented in Table (5). Water quality parameters were measured every to weeks during (June, July, August, September and October) the course of the experiment. As presented in this table, water temperature ranged between 24 to $30.9^{\circ} \mathrm{C}$, DO concentration ranged between 6.3 and $9 \mathrm{mg} / 1$, transparency 37 to $52 \mathrm{~cm}, \mathrm{pH} 7.3$ to 7.9 degrees, $\mathrm{NH}_{3} 0.022$ to $0.033 \mathrm{mg} / 1$ and TDS between 8610 and $9580 \mathrm{mg} / 1$ and all tested water quality parameters were within the 
optimal levels required for growth and development of Nile tilapia and were in accordance with the levels of APHA (1985)

Table (5) Monthly average water quality parameter during the experimental period in the cement ponds.

\begin{tabular}{|l|l|l|l|l|l|l|}
\hline \multirow{2}{*}{ Month } & \multicolumn{6}{|c|}{ Parameters } \\
\cline { 2 - 7 } & \multicolumn{1}{|c|}{ Temperature $\left({ }^{\circ} \mathrm{C}\right)$} & $\begin{array}{c}\text { DO. } \\
(\mathrm{mg} / \mathrm{l})\end{array}$ & $\begin{array}{c}\text { Transp. } \\
(\mathrm{Cm})\end{array}$ & $\mathrm{pH}$ & $\begin{array}{c}\text { NH3 } \\
(\mathrm{mg} / \mathrm{l})\end{array}$ & $\begin{array}{c}\text { TDS } \\
(\mathrm{mg} / \mathrm{l})\end{array}$ \\
\hline June & 25.1 & 9 & 52 & 7.9 & 0.025 & 8720 \\
\hline July & 28.5 & 8.2 & 43 & 7.8 & 0.029 & 8610 \\
\hline August & 30.9 & 7.5 & 45 & 7.5 & 0.022 & 8670 \\
\hline September & 29.2 & 6.8 & 42 & 7.3 & 0.031 & 9580 \\
\hline October & 24 & 6.3 & 37 & 7.7 & 0.033 & 8800 \\
\hline
\end{tabular}

Growth performance: Growth performance parameters of Nile tilapia as affected with replacement of yellow corn with sweet potato as energy source at levels 25; 50 and 100\% (as energy) including final weight (FW); total weight gain (TWG); daily weight gain (DWG); specific growth rate (SGR); condition factor $(\mathrm{K})$ and survival rate (SR), are presented in Table (6).

Results of the same table indicate that average initial weights at the experimental start were found to be $0.31 \mathrm{~g}$ for all dietary treatment groups.

Averages of final weight (FW) for the control (CSP0); culled sweet potato at level $25 \%$ (CSP25); 50\% (CSP50) and 100\% (CSP100), were 81.39; $78.83 ; 88.15$ and $93.05 \mathrm{~g}$ respectively. Analysis of variance for FW indicate that the group CSP100 recorded significantly $(\mathrm{p}<0.05)$ the highest final weight followed in a significant $(\mathrm{p}<0.05)$ decreasing order by CSP50 and both CSP0 and CSP25, respectively. The same trend was observed in TWG where the group CSP100 recorded the highest $(\mathrm{p}<0.05)$ value followed by the CSP50 and the CSP0 and 25 groups, respectively. Concerning averages of SGR; results of the same table show that SGR values for the CSP0; CSP25; CSP50 and CSP100 were $3.62 ; 3.6 ; 3.67$ and 3.7 , respectively. The results indicate also that groups CSP100 and CSP50 had significantly $(\mathrm{p}<0.05)$ higher SGR values compared to the CSP0 and CSP25 groups. Results of Table (6) indicate that K values ranged between 1.82 and 1.84 with insignificant differences among the dietary treatment groups which reveal that the fish in all groups grow almost equal in weight in relation to length. Results also show that survival rates ranged between $89.63 \%$ (CSP25 group) and $92.96 \%$ (group CSP50) with insignificant differences among the treatment groups. In general, results concerning growth performance as affected with replacing yellow corn with sweet potato as dietary energy source indicate that yellow corn energy in growing Nile tilapia diets can be completely replaced with sweet potato or partially at $50 \%$ replacement level

These results are in accordance with the findings of Olukunle (2006) who reported that replacing the energy of yellow corn with energy with sweet potato peel (SPP) at 25; 50 and $75 \%$ improved growth performance parameters of African catfish compared to the control group and the improvement in growth 
parameters was more pronounced at $25 \%$ replacement levels. The author added that the percentages of weight gain for the control; 25; 50; and $75 \%$ groups were $101.54 ; 150.77 ; 132.31$ and $127.6 \%$, respectively. Also, Soltan et al. (2005) incorporated potato by-product meal (PBM) to replace $10 ; 20 ; 30 ; 40$ and 50\% of yellow corn in common carp diets. They reported that the higher replacing level $(50 \%)$ of yellow corn by (PBM) in carp diets significantly decreased BW, WG and SGR. Furthermore, Ghazalah et al. (2002) found that, replacing 25 or $50 \%$ of YC with PBM did not significantly changed BW, WG and SGR of Nile tilapia (O. niloticus). On the other hand, Shouqi et al. (1997) concluded that as dietary potato protein concentrate increased from 0 to $51 \%$ in rainbow trout (Oncorhynchus mykiss) diets, final BW and SGR significantly decreased and mortality increased.

Table (6): Growth performance of Nile tilapia fed on Culled Sweet Potato as non-traditional energy feedstuffs place corn in diet

\begin{tabular}{|l|l|l|l|l|}
\hline \multirow{2}{*}{ Parameter } & \multirow{2}{*}{ control } & \multicolumn{3}{|c|}{ CSP } \\
\cline { 3 - 5 } & & \multicolumn{1}{|c|}{$\mathbf{2 5 \%}$} & \multicolumn{1}{|c|}{$\mathbf{5 0 \%}$} & $\mathbf{1 0 0 \%}$ \\
\hline Initial weight $(\mathrm{g})$ & $0.31^{\mathbf{a}} \pm 0.00$ & $0.31^{\mathbf{a}} \pm 0.00$ & $0.31^{\mathbf{a}} \pm 0.00$ & $0.31^{\mathbf{a}} \pm 0.00$ \\
\hline Final weight $(\mathrm{g})$ & $81.39^{\mathbf{c}} \pm 1.27$ & $78.83^{\mathbf{c}} \pm 1.64$ & $88.15^{\mathbf{b}} \pm 1.3$ & $93.05^{\mathbf{a}} \pm 1.21$ \\
\hline Total weight gain (g) & $81.08^{\mathbf{c}} \pm 1.27$ & $78.52^{\mathbf{c}} \pm 1.64$ & $87.84^{\mathbf{b}} \pm 1.3$ & $92.74^{\mathbf{a}} \pm 1.21$ \\
\hline Daily Weight gain (g) & $0.53^{\mathbf{b}} \pm 0.01$ & $0.51^{\mathbf{b}} \pm 0.01$ & $0.57^{\mathbf{a}} \pm 0.01$ & $0.6^{\mathbf{a}} \pm 0.01$ \\
\hline SGR & $3.62^{\mathbf{b}} \pm 0.01$ & $3.6^{\mathbf{b}} \pm 0.01$ & $3.67^{\mathbf{a}} \pm 0.01$ & $3.7^{\mathbf{a}} \pm 0.01$ \\
\hline Condition factor & $1.82^{\mathbf{a}} \pm 0.01$ & $1.84^{\mathbf{a}} \pm 0.01$ & $1.84^{\mathbf{a}} \pm 0.0$ & $1.83^{\mathbf{a}} \pm 0.0$ \\
\hline Survival Rat \% & $91.3^{\mathbf{a}} \pm 1.03$ & $89.63^{\mathbf{a}} \pm 1.03$ & $92.96^{\mathbf{a}} \pm 1.21$ & $90.56^{\mathbf{a}} \pm 0.85$ \\
\hline
\end{tabular}

a, b, c...etc.: Means within row with different superscripts are significantly different $(\mathrm{P}<0.05)$

In this connection, Saleh (2001) reported that yellow corn can be substituted by either $25 \%$ date stone (DSM) or up to till $50 \%$ potato by-product meal (PBM) in Nile tilapia diets without harmful effect on the growth performance and feed utilization of fish. Furthermore, Ufodike and Matty (1988) fed the rainbow trout (Salmo garidenii) fingerlings on diets containing 10; 20 and $30 \%$ corn or potato waste. They found that nutrient digestibility and growth results indicate that the increase either in dietary corn or potato waste yield greater weight gain and better SGR, PER and apparent net protein utilization (NPU). On the other hand Degani et al. (1986) found that potato starch had less effect on growth than wheat meal, bread meal or soluble corn starch by European eels. Also, Omoregie et al. (2009) incorporated sweet potato peel (SPP) in Nile tilapia diets (0.46 - $0.48 \mathrm{~g}$ initial weight) at levels of $0 ; 5 ; 10 ; 15$; 20 and 25 percent in iso nitrogenous (31.22\% crude protein) diets and found that the greatest increase in body weight $(1.30 \pm 0.07 \mathrm{~g})$ of the fish was achieved with the control diet $(\mathrm{p}<0.05)$. This was followed by fish fed diet with $5 \%$ of the peel $(0.90 \pm 0.09 \mathrm{~g})$ while the least increase in body weight $(0.46 \pm 0.01 \mathrm{~g})$ was obtained in the fish fed diet with $25 \%$ of the peel $(\mathrm{p}<0.05)$.

The disagreement among results of the present study (Table 6) and the results of Omoregie et al. (2009) may be due to the fact that they used SPP, 
while in the present work the whole sweet potato roots were used which contain more starch and sugars available as energy source.

Feed utilization: Results of total amount of feed consumed (g / fish); total gain in weight; feed conversion ratio, (g. feed required for each g. gain in weight); protein efficiency ratio (PER); protein productive value (PPV) and energy utilization (EUR) are illustrated in Table (7).

Results in this table reveal that total feed intake (per fish) increased as the level of CSP in Nile tilapia diets increased. The same trend was observed with total gain in weight except for the CSP25 group.

Averages of FCR for the CSP0; CSP25; CSP50 and CSP100 groups were found to be 2.04, 2.15, 1.94 and 2.01. Analysis of variance for FCR indicates that the CSP0, CSP50 and CSP 100 groups had significantly $(\mathrm{p}<0.05)$ better (lower) FCR compared to the CSP25 group. These results indicate that the CSP25 group consumed more diet but gained less weight compared to the other groups. Averages of PER for the CSP0; CSP25; CSP50 and CSP100 groups were $1.49 ; 1.41 ; 1.56$ and 1.51 , respectively and the highest $(\mathrm{p}<0.05)$ values were obtained by CSP50 and CSP100 compared to the CSP25 group; however differences among the CSP0 group and CSP50 and CSP100 in PER were insignificant. Averages of PPV ranged between 24.87 (CSP25 group) and 26.14(CSP100 group) with insignificant differences among the dietary treatments groups; which indicate that replacing yellow corn energy with sweet potato energy resulted in an insignificant effect in protein utilization. As indicated in Table (7), EUR \% for groups CSP0, CSP25, CSP50 and CSP100 were $16.44,16.56,16.94$ and $17.15 \%$; respectively with insignificant differences among the treatment groups; however EUR\% tended to increase with each increase in CSP replacement level.

In this respect, Olukunle (2006) reported that the highest feed conversion efficiency (FCE) and (PER) were observed in African catfish with diets containing $25 \%$ sweet potato peel (SPP) compared to diets contained 50 or $75 \%$ SPP in replacement with yellow corn. Soltan et al. (2005) reported that replacement of yellow corn with potato by-products meal at $50 \%$ level significantly improved FCR and PER compared to higher or lower replacement level in common carp diets. Also Saleh (2001) substituted yellow corn by date stone meal (DSM) or potato by-products meal (PBM) at 25, 50 and $75 \%$ levels in Nile tilapia diets. She reported that yellow corn energy can be substituted by either $25 \%$ DSM or up to $50 \%$ PBM without harmful effects in nutrients utilization.

Recently, Omoregie et al., (2009) incorporated sweet potato peel (SPP) in Nile tilapia diets at $0,5,10,15,20$ and $25 \%$ levels and found that PER, apparent net protein utilization values were $2.14,1.88,1.59,1.70,1.45$ and 1.13 for PER and 27.14, 33.55, 30.42, 23.24, 31.79 and 14.04 for ANPU respectively. The same authors reported that the best FCR value 1.49 and 1.71 were recorded 
by the control and SPP5 groups; respectively, while that of the other groups (SPP20 and SPP25) were significantly higher (worst).

Table (7) Feed utilization of Nile tilapia fed on Culled Sweet Potato as non-traditional energy feedstuffs place corn in diet

\begin{tabular}{|l|l|l|l|l|}
\hline \multirow{2}{*}{ Parameter } & \multirow{2}{*}{ Control } & \multicolumn{3}{|c|}{ CSP } \\
\cline { 3 - 5 } & & \multicolumn{1}{|c|}{$\mathbf{2 5 \%}$} & $\mathbf{5 0 \%}$ & \multicolumn{1}{|c|}{$\mathbf{0 0 \%}$} \\
\hline Total feed intake g/fish & 165.25 & 168.88 & 170.58 & 186.82 \\
\hline Total weight gain g/fish & 81.08 & 78.52 & 87.84 & 92.74 \\
\hline FCR & $2.04^{\mathbf{b}} \pm 0.02$ & $2.15^{\mathbf{a}} \pm 0.02$ & $1.94^{\mathbf{b}} \pm 0.04$ & $2.01^{\mathbf{b}} \pm 0.03$ \\
\hline PER & $1.49^{\mathbf{a}} \pm 0.02$ & $1.41^{\mathbf{b}} \pm 0.02$ & $1.56^{\mathbf{a}} \pm 0.04$ & $1.51^{\mathbf{a}} \pm 0.02$ \\
\hline PPV & $25.06^{\mathbf{a}} \pm 0.27$ & $24.87^{\mathbf{a}} \pm 0.27$ & $25.96^{\mathbf{a}} \pm 0.6$ & $26.14^{\mathbf{a}} \pm 0.4$ \\
\hline EUR & $16.44^{\mathbf{a}} \pm 0.18$ & $16.56^{\mathbf{a}} \pm 0.18$ & $16.94^{\mathbf{a}} \pm 0.39$ & $17.15^{\mathbf{a}} \pm 0.26$ \\
\hline
\end{tabular}

$\mathrm{a}, \mathrm{b}, \mathrm{c} \ldots$...tc.: Means within row with different superscripts are significantly different $(\mathrm{P}<0.05)$

Carcass traits: Averages of carcass traits (as percentage of body weight) are presented in Table (8). Averages of dressing percentage (fish body without head; fins; viscera and scales) for the groups CSP0, CSP25, CSP50 and CSP100 were found to be 59.92, 62.33, 62.03 and 62.91 percent respectively. Results of dressing percentage revealed that replacement of yellow corn energy with sweet potato at 25,50 or $100 \%$ levels improved significantly $(p<0.05)$ this trait compared to the control group. On the other hand the CSP0 and CSP50 groups recorded the highest head percentages compared to the CSP100 group. Averages of by-products (body weight - flesh weight) percentage were 48.05, 46.97, 47.17 and $46.18 \%$ for the CSP0, CSP25, CSP50 and CSP100 respectively. Results revealed that the CSP100 group recorded the lowest $(\mathrm{p}<0.05)$ by-products percentages while the CSP0 group recorded the highest $(\mathrm{p}<0.05)$ value. Concerning flesh\% results of table (8) group CSP100 recorded the highest flesh percentage followed in a significant decreasing $(\mathrm{p}<0.05)$ order by the CSP50 and the control groups; however differences among CSP100 and CSP25 in flesh percentage were insignificant.

These results are in partial accordance with the findings of Soltan et al. (2005) who reported that incorporation of potato by-product meal (PBM) in replacement of yellow corn at up to $30 \%$ level did not significantly affect the percentages of dress out and flesh in carp carcass; while the percentages of fish by-products increased significantly with increasing the replacing level of YC by PBM in carp diets. However; diet PBM50 released the highest (56.34) percentage of by-products compared to the control diet which recorded the lowest value $(51.92 \%)$.

In this respect, Soltan (2002) found that replacing YC by PBM up to 40 and $70 \%$ did not significantly affect the percentages of dress-out and flesh in tilapia carcass. Also results of El-Garhy (2003) are in partial agreement with the results in Table (8) where he stated that wastes of potato chippsy could be incorporated in Nile tilapia diets up to $50 \%$ in replacement with yellow corn without any adverse effects on growth performance, carcass characteristics and meat quality. 
Table (8): Carcass parameters of Nile tilapia fed on Culled Sweet Potato as non-traditional energy feedstuffs place corn in diet

\begin{tabular}{|l|l|l|l|l|}
\hline \multirow{2}{*}{ Ingredint } & \multirow{2}{*}{ Control } & \multicolumn{3}{|c|}{ CSP } \\
\cline { 3 - 5 } & & \multicolumn{1}{|c|}{$\mathbf{2 5 \%}$} & $\mathbf{5 0 \%}$ & $\mathbf{1 0 0 \%}$ \\
\hline DRESSING \% & $59.92^{\mathbf{b}} \pm 0.32$ & $62.33^{\mathbf{a}} \pm 0.33$ & $62.03^{\mathbf{a}} \pm 0.29$ & $62.91^{\mathbf{a}} \pm 0.28$ \\
\hline HEAD \% & $19.6^{\mathbf{a}} \pm 0.23$ & $19.31^{\mathbf{a b}} \pm 0.18$ & $19^{\mathbf{b c}} \pm 0.16$ & $18.63^{\mathbf{c}} \pm 0.19$ \\
\hline BY-PRODUCT \% & $48.05^{\mathbf{a}} \pm 0.33$ & $46.97^{\mathbf{b c}} \pm 0.37$ & $47.17^{\mathbf{a b}} \pm 0.3$ & $46.18^{\mathbf{c}} \pm 0.29$ \\
\hline FLESH \% & $51.95^{\mathbf{c}} \pm 0.33$ & $53.03^{\mathbf{a b}} \pm 0.37$ & $52.83^{\mathbf{b c}} \pm 0.3$ & $53.82^{\mathbf{a}} \pm 0.29$ \\
\hline
\end{tabular}

$\mathrm{a}, \mathrm{b}, \mathrm{c} \ldots$...tc.: Means within row with different superscripts are significantly different $(\mathrm{P}<0.05)$

Whole body chemical composition: Results of whole body chemical composition as percentage on dry matter basis for crude protein, fat and ash of Nile tilapia as affected with culled sweet potato (CSP) incorporation in the diet to replace yellow corn as energy source are presented in Table (9). Results of this table reveal that dry matter (DM) contents in whole fish bodies ranged between 27.11 and $29.24 \%$, protein contents ranged between 60.18 and $61.22 \%$, fat contents ranged between 20.95 and $21.91 \%$ and ash contents ranged between 17.72 and $18.87 \%$ with insignificant differences in all of these parameters among the dietary treatments. These results indicate that incorporation of CSP in Nile tilapia diets to replace $100 \%$ of the yellow corn as energy source released no significant effects on whole body composition of Nile tilapia.

Table (9): Chemical composition of Nile tilapia fed on Culled Sweet Potato as non-traditional energy feedstuffs place corn in diet

\begin{tabular}{|l|l|l|l|l|}
\hline \multirow{2}{*}{ Ingredient } & \multirow{2}{*}{ Control } & \multicolumn{3}{|c|}{ CSP } \\
\cline { 3 - 5 } & & \multicolumn{1}{|c|}{$\mathbf{2 5 \%}$} & \multicolumn{1}{|c|}{$\mathbf{5 0 \%}$} & \multicolumn{1}{|c|}{$\mathbf{1 0 0 \%}$} \\
\hline Moisture & $72.32^{\mathbf{a}} \pm 1.13$ & $70.76^{\mathbf{a}} \pm 0.03$ & $72.89^{\mathbf{a}} \pm 0.53$ & $71.17^{\mathbf{a}} \pm 0.73$ \\
\hline Dry matter & $27.68^{\mathbf{a}} \pm 1.13$ & $29.24^{\mathbf{a}} \pm 0.03$ & $27.11^{\mathbf{a}} \pm 0.53$ & $28.83^{\mathbf{a}} \pm 0.73$ \\
\hline Protein & $60.8^{\mathbf{a}} \pm 0.47$ & $60.25^{\mathbf{a}} \pm 0.31$ & $61.22^{\mathbf{a}} \pm 0.58$ & $60.18^{\mathbf{a}} \pm 0.58$ \\
\hline Fat content & $21.11^{\mathbf{a}} \pm 0.35$ & $21.91^{\mathbf{a}} \pm 0.28$ & $21.06^{\mathbf{a}} \pm 0.23$ & $20.95^{\mathbf{a}} \pm 0.49$ \\
\hline Ash content & $18.09^{\mathbf{a}} \pm 0.48$ & $17.84^{\mathbf{a}} \pm 0.41$ & $17.72^{\mathbf{a}} \pm 0.71$ & $18.87^{\mathbf{a}} \pm 0.19$ \\
\hline
\end{tabular}

a, b, c...etc.: Means within row with different superscripts are significantly different $(\mathrm{P}<0.05)$

In this respect, Soltan et al. (2005) reported that inclusion of potato byproduct meal (PBM) in common carp diets in replacement with yellow corn at 0 ; $10 ; 20 ; 30 ; 40$ or $50 \%$ levels released insignificant effects on moisture contents of the whole fish body. They added that incorporation of PBM in crap diets at highest level (50\%) significantly decreased the protein contents of the fish body and the opposite trend was observed for the ash contents. The same authors added that all replacing levels of yellow corn by PBM significantly decreased fat contents in fish bodies compared to the control group. Results of Table (9) disagree with the findings of Soltan (2002) who found that increasing the inclusion level of PBM up to $50 \%$ in tilapia diets did not significantly change the protein content but the higher inclusion levels $(60,70$ or $80 \%)$ significantly decreased protein and ash contents of tilapia bodies. Shouqi et al. (1997) reported that, CP content of fish decreased $(\mathrm{p}<0.05)$ as dietary potato protein concentrate increased from 0 to $51 \%$ in rainbow trout (Oncorhynchus mykiss) 
diets. Also, Xie and Jokumsen (1997) cleared that incorporation of potato protein concentrate in diets of rainbow trout significantly increased ash contents of fish body. Furthermore, Olukunle (2006) reported that incorporation of sweet potato peel (SPP) meal in African catfish diets at levels of $0,25,50$ and $75 \%$ in replacement to maize had no significant effects on carcass composition of African catfish at the end of the feeding trail, which is in partial agreement with results of the present results. Recently, Omoregie et al. (2009) replaced yellow corn in Nile tilapia diets with SPP at $0,5,10,15,20$, and $25 \%$ levels in iso nitrogenous diets $(31.23 \%$ protein) for 10 weeks. They reported that carcass of fish fed on diet containing SPP25 had the lowest protein content, which was significantly different from the other diets except SPP15. The ash content was nearly constant, as there was no significant difference among the six experimental diets. Fish fed diet SPP0 recorded the highest level of lipid deposit which was significantly different from the other dietary treatments.

Economical evaluation: Average costs of one $\mathrm{kg}$ formulated diet for $\mathrm{T} 1,25,50$ and $100 \%$ CSP groups were found to be $2.966,2.972,2.968$ and $2.963 \mathrm{LE}$; respectively. Results revealed that the costs of the experimental diets were almost similar to that of the control group. This may be due to the use of higher level of soybean meal and oil in the formulation of CSP diets to adjust the protein and energy contents which results in iso caloric iso nitrogenous experimental diets. Averages of feed costs for each $\mathrm{kg}$ gain in weight in LE for the same groups cited above were 6.045, 6.391, 5.763 and 5.97 LE; respectively (table 10). As presented in the same table average percentages of feed costs based of the costs of the control group (100\%) were found to be 105.72, 95.33 and $98.76 \%$ for the CSP25, CSP50 and CSP100 groups respectively. Furthermore; results of table (11) show that costs of 1000 Kcal from CSP was $0.168 \mathrm{LE}$, while that of yellow corn was $0.229 \mathrm{LE}$ which show that $1000 \mathrm{Kcal}$ from CSP is about $26.63 \%$ lower than that of yellow corn.

In this connection, Olukunle (2006) incorporated sweet potato peel SPP in African catfish diets at levels of 25, 50 and $75 \%$ in replacement with maize; and found that the SPP meal based diets were cheaper than the control diet. The same author reported also that the gain in weight costs can be reduced with SPP, while maintaining a high yield. Also Soltan et al. (2005) incorporated potato byproducts meal (PBM) in practical diets of common carp to replace yellow corn and found that it reduced the feed costs for one $\mathrm{kg}$ gain in weight to 83.47, $89.07,87.47,77.60$ and $86.40 \%$ of the control group when PBM was incorporated at 10, 20,30,40, and $50 \%$ levels in replacement with yellow corn as cheaper energy source.

Results of Saleh (2001) revealed that incorporation of PPM in Nile tilapia diets at 25 and $50 \%$ levels to replace yellow corn reduced the feed costs required for each $\mathrm{kg}$ gain in weight by 1.35 and $6.22 \%$ respectively while at $75 \%$ replacement level increased the costs of feed to produce one $\mathrm{kg}$ gain in weight by 1.08 compared to the yellow corn control group. 
Table (10) feed cost (L.E) for one $\mathrm{Kg}$ weight gain produced by fish fed on Culled Sweet Potato as non-traditional energy feedstuffs place corn in diet (2006)

\begin{tabular}{|l|l|l|l|l|}
\hline \multirow{2}{*}{ Treatment } & Control & CSP & \multicolumn{2}{|l|}{} \\
\cline { 3 - 5 } & & $\mathbf{2 5 \%}$ & $\mathbf{5 0 \%}$ & $\mathbf{1 0 0 \%}$ \\
\hline Feed intake g/fish & 165.25 & 168.88 & 170.58 & 186.82 \\
\hline Cost (L.E) of one Kg of feed & $\mathbf{2 . 9 6 6}$ & $\mathbf{2 . 9 7 2}$ & $\mathbf{2 . 9 6 7 7}$ & $\mathbf{2 . 9 6 4}$ \\
\hline Total weight gain g/fish & 81.08 & 78.52 & 87.84 & 92.74 \\
\hline Feed cost/Kg gain L.E & 6.045 & 6.391 & 5.763 & 5.97 \\
\hline $\begin{array}{l}\text { Percentage decrease in feed } \\
\text { cost to produce one Kg fish } \\
\text { gain }\end{array}$ & $\mathbf{1 0 0}$ & $\mathbf{1 0 5 . 7 2 ( + 5 . 7 2 )}$ & $\mathbf{9 5 . 3 3 \quad ( - 4 . 6 7 )}$ & $\mathbf{9 8 . 7 6} \mathbf{( - 1 . 2 4 )}$ \\
\hline
\end{tabular}

Table (11) Price comparison for $1000 \mathrm{~K}$ calories between culled sweet potato and corn (2006)

\begin{tabular}{|l|l|l|}
\hline item & CSP & Yellow corn \\
\hline 1 ton cost $($ L.E.) & 618 & 890 \\
\hline $\mathrm{K}$ cal $/ \mathrm{Kg}$ & 3671 & 3881 \\
\hline $1000 \mathrm{~K}$ cal. cost $($ L.E.) & $\mathbf{0 . 1 6 8}$ & $\mathbf{0 . 2 2 9}$ \\
\hline
\end{tabular}

Results of Table (10) are in partial agreement with the findings of ElGarhy (2003). Who incorporated potato by-products (PB), macaroni by-products waste MP or a mixture of both $(50 \% \mathrm{~PB}+50 \% \mathrm{MP})$ to replace 25 or $50 \%$ of yellow corn energy in Nile tilapia diets. He found that incorporation of PB or MP or in combination in tilapia diets reduced the feed costs by about 7.35, 5.39 and $3.43 \%$ compared to the control corn diet. He attributed the reduction in diet costs to lower prices of PB and MP compared to yellow corn at the time of his study. The author found that feed costs required for production of one $\mathrm{kg}$ gain in weight for control, PB, PB + MP and MP groups respectively. The reduction in the costs to produce one $\mathrm{kg}$ gain in weight compared to the control group for $\mathrm{PB}$, PB + MP and MP groups were 23.11, 19.92 and 19.52\% respectively.

Based on the obtained results in this experiment yellow corn growing in Nile tilapia diet could be completely replaced by culled sweet potato without any adverse effects on fish growth performance, nutrients utilization or feed and production costs. The advantages of using CSP as dietary energy source may relie on the fact that CSP is locally produced in low price compared to the imported and not always available yellow corn

\section{REFFRENCES}

Abdel-Hakim, N.F.; Al-Azab, A.A. and El- Kholy (2003). Effect of feeding some full fat oil seeds on performance of tilapia hybrid (Oreochrornis niloticus $X$ O. aureus) reared in tanks. Egyptian J. Nutrition and feeds, 6 (Special Issue): 389- 403.

AOAC (Association of Official Analytical Chemists), (1990). Official Methods of Analysis ( $15^{\text {th }}$ ed.) AOAC Inc. Arlington, Virginia, USA, 1094pp.

APHA, (1985). American Public Health Association, Standard methods for the examination of water and waste water. (16th edition), Washington, D.C. 
Boyd, C. E. (1992). Water quality in warm water fish. Alabama Agric. Experiment Station, Auburn Univ. Alabama.

Dauncan, D. (1955). Multiple range and Multiple (F) tests. Biometrics, 11: 1-2.

Degani, G.; Viola, S. and Levanon, D. (1986). Effects of dietary carbohydrate source on growth and body composition of European eels (Anguilla anguilla L.). Aquaculture, 104:293-308.

El-Garhy, M.A. (2003). Using some non-conventional feedstuffs in fish feeding. Ph.D. Thesis. Faculty of Agriculture, Cairo University.

Ghazalah, A. A.; Gomaa, I. A. and Hyam D. Tonsy (2002). The use of date stone meal (DSM) and potato by-product meal (PBM) as non- conventional energy feed sources in Nile tilapia (Oreochromis niloticus) diets. The $1 \mathrm{st}$ Scientific Conference of the Egyptian Aquaculture Society, El-Arish, North Sinai, Egypt, 13-15 December, 2002.

Jobling, M.(1983). A short review and critique of methodology used in fish growth and nutrition studies. J. fish biology, 23: 685-703.

Kubaryk, J. M. (1980). Effect of diet, feeding schedule and sex on food consumption, growth and retention of protein and energy by tilapia. Ph.D. Dissertation. Auburn University, Auburn, Alabama.

Li, L. (1974). Variation in protein content and its relation to other characters in sweet potatoes. J. of the Agricul. Association of China, 88:17-22.

Lovell, R. T. (1981). Laboratory Manual for Fish Feed Analysis and Fish Nutrition Studies. Auburn University, Alabama.

Middleton,T. F.; Ferket, P.R.; Boyd, L.C.; Daniels, H.V. and Gallagher, M.L.(2001). An evaluation of co-extruded poultry silage and culled jewel sweet potatoes as a feed ingredient for hybrid Tilapia (Oreochromis niloticus X O. Mossambicus). Aquaculture 198 (2001) 269-280

Olukunle, O.A. (2006). Nutritive Potential of Sweet Potato Peel Meal and Root Replacement Value for Maize in Diets of African Catfish (Clarias gariepinus) Advanced Fry. Journal of Food Technology 4 (4): 289-293, 2006

Omoregie, E.; Igoche, L.; Ojobe, TO; Absalom, KV. and Onusiriuka, BC. (2009): Effect of varying levels of sweet potato (Ipomea batatas) peels on growth, feed utilization and some biochemical responses of the cichlid (Oreochromis niloticus). Ajfand online, march, 2009, 9 (2):700712

Purcell, A.E.; Walter, W.M. and Giesbrecht, F.G. (1976). Distribution of protein within sweet potato roots (Ipomoea batatas L.). Journal of Agriculture and Food Chemistry, 24: 64 - 66.

Saleh H. d. Tonsy (2001). The use of non-conventional energy and protein feed sources in Nile tilapia diets. Ph. D., Animal Production Department, Faculty of Agriculture, Cairo University. 
Shouqi, X.; Jokumsen, A. and Sq, X. (1997). Replacement of fish meal by potato protein concentrate in diets for rainbow trout, Oncorhynchus mykiss (Walbaum): growth, feed utilization and body composition. Aquaculture Nutrition, 3:65-69.

Soltan M.A.; Abdella, M.M.; Abou-Seif, R.A. and Hassan, M.S. (2005). Using of tomato and potato by-products as partial replacements soybean meal and yellow corn in practical diets for the common carp (cyprinus carpio). Egyptian J. Nutrition and feeds. 8(2). 257-272

Soltan, M. A. (2002). Using of tomato and potato by-products as nonconventional ingredients in Nile tilapia, Oreochromis niloticus diets. Annals of Agric. Sci., Moshtohor, 40(4):2081-2096.

SPSS 14.0 statistical program for windows., Copyright $($ ) SPSS Inc.

Ufodike, E. B. C. and Matty, A. G. (1988). Growth responses and nutrient digestibility in mirror carp (Cyprinus carpio) fed different levels of cassava and rice. Aquaculture, 31:41-50.

Walter, W.M.; Collins, W.W.; and Purcell, A. E. (1984). Sweet potato protein: a review. Journal of Agricultural Food Chemistry, 32: 695 - 697.

Windows Xp., Professional Edition, Version 2002 Service Pack 2., Microsoft Co-operation.

Xie, S. and Jokumsen, A. (1997). Incorporation of potato protein concentrate in diets for rainbow trout effect on feed intake, growth and feed utilization. Aquaculture Nutrition, 3(4):223-226. 